\title{
Erratum: Structure Model Index Does Not Measure Rods and Plates in Trabecular Bone
}

\section{Frontiers Production Office*}

Frontiers Production Office, Frontiers, Switzerland

Keywords: SMI, EF, geometry, ellipsoid, measurement

\section{A Erratum on}

Structure Model Index Does Not Measure Rods and Plates in Trabecular Bone

by Salmon, P. L., Ohlsson, C., Shefelbine, S. J., and Doube, M. Front Endocrinol (2015) 6:162. doi: 10.3389/fendo.2015.00162

\section{Reason for Erratum}

Due to a typesetting error the word "trabeculae" was changed to an incorrect spelling of "trabecule." The publisher apologizes for this mistake and the original article has been updated. This error does not change the scientific conclusions of the article in any way.

OPEN ACCESS

Approved by: Endocrinology Editorial Office, Frontiers, Switzerland

*Correspondence:

Frontiers Production Office production.office@frontiersin.org

Specialty section: This article was submitted to Bone Research, a section of the journal Frontiers in Endocrinology

Received: 11 November 2015 Accepted: 11 November 2015 Published: 16 November 2015

Citation: Frontiers Production Office (2015) Erratum: Structure Model Index Does Not Measure Rods and Plates in Trabecular Bone. Front. Endocrinol. 6:181. doi: 10.3389/fendo.2015.00181
Copyright $\odot 2015$ Frontiers Production Office. This is an open-access article distributed under the terms of the Creative Commons Attribution License (CC BY). The use, distribution or reproduction in other forums is permitted, provided the original author(s) or licensor are credited and that the original publication in this journal is cited, in accordance with accepted academic practice. No use, distribution or reproduction is permitted which does not comply with these terms. 